\title{
INDIAN AGENT INVOLVEMENT IN THE ESTABLISHMENT OF PERMANENT SETTLEMENT FOR THE SOUTH INDIAN LABOURING COMMUNITY, 1923-1941
}

\section{Utaman Raman" and Sivachandralingam Sundara Raja}

Department of History, Faculty of Arts and Social Sciences, Universiti Malaya, Kuala Lumpur, MALAYSIA

*Corresponding author: utam1971@gmail.com

Published online: 29 October 2021

To cite this article: M. Utaman Raman and Sivachandralingam Sundara Raja. 2021. Indian agent involvement in the establishment of permanent settlement for the south Indian labouring community, 1923-1941. Kajian Malaysia 39(2): 95-115. https://doi.org/10.21315/km2021.39.2.5

To link to this article: https://doi.org/10.21315/km2021.39.2.5

\begin{abstract}
This article investigates a long-neglected aspect of Indian Malaysian history, namely the Indian Agents of the Government of India to British Malaya. The Indian Agents were representatives of the Indian Government who were appointed under the Indian Immigration Act of 1922 to investigate and report on the state of affairs of Indian communities in the British colonies. The official duties of the Indian Agents in British Malaya were formalised under Section 73 (III) of the Labour Code 1923. Between 1923 and 1941, six Indian Agents were appointed in British Malaya. Throughout their tenure, they focused on and reported extensively on the socioeconomic conditions of the Indian working-class community, particularly south Indian labourers. One problem that came to their attention was the underdevelopment of the community's permanent settlement in the country. The Federated Malay States (FMS) government did not appear to be concerned about the situation. Similarly, private estate managers reacted indifferently to the issue. Both saw permanent settlement as simply an economic measure to keep the community as a labour force, rather than a way to alleviate their socioeconomic hardships. This article shows how the Indian Agents were able to uncover a range of issues that were impeding the establishment of permanent settlements for south Indian labourers in the FMS. Some of them demonstrated exceptional levels of
\end{abstract}


direct involvement. The article's primary goal is to assess the degree to which the Indian Agents influenced the overall development of permanent Indian labour settlement.

Keywords: Indian Agents, south Indian labourers, permanent settlement, great depression

\section{INTRODUCTION}

Despite the fact that the history of Indian Malaysians has been the topic of numerous scholarly publications over the years, there are still areas that researchers have yet to fully investigate. The role of the Indian Agent of the Government of India is one such understudied aspect. The Indian Agents were representatives appointed by the British Governor-General of India under Section 7 of the Indian Immigration Act 1922 to protect and safeguard the rights of Indian immigrants residing overseas, including in British Malaya (Raghavan 1954). Section 56 of the Indian Immigration Rules 1923 specified the roles and obligations of the Indian Agent in clauses (2), (3) and (4). Periodic visits to working sites where Indians were employed, investigation of welfare problems such as settlement formation, working conditions, and education, as well as legal advice and protection, and finally submission of a report to the local and Indian colonial governments, were all part of this (Nair 1937). In British Malaya, their official obligations were covered by Section 73 (III) of the Labour Code 1923, which was passed in accordance with the Indian Emigration Act 1922 (Belle 2015). The Indian Agents were usually British government officials from the Madras Provincial Civil Service (PCS) and the Indian Civil Service (ICS). Table 1 shows six Indian Agents were appointed in Malaya between 1923 and 1941.

The appointment of the first Agent of the Government of India to Malaya in 1923 was made in response to the continuing worsening of the socioeconomic position of working-class south Indians and the Malayan government's inability to adopt an effective approach to their various problems. However, the events that led to the placement of an Agent in British-held territories where Indians were present can be traced back to the broader context of a crucial policy reform implemented in British India in 1919. The Montague-Chelmsford Reforms, also known as the Mont-Ford Reform, were adopted in this year to increase the involvement of local Indians in administration and, thereby, to pave the way for the eventual implementation of self-governing institutions (Witherington $1937,3)$. The reform resulted in the ratification of the Government of India Act 
Indian Agents and Permanent Indian Settlement

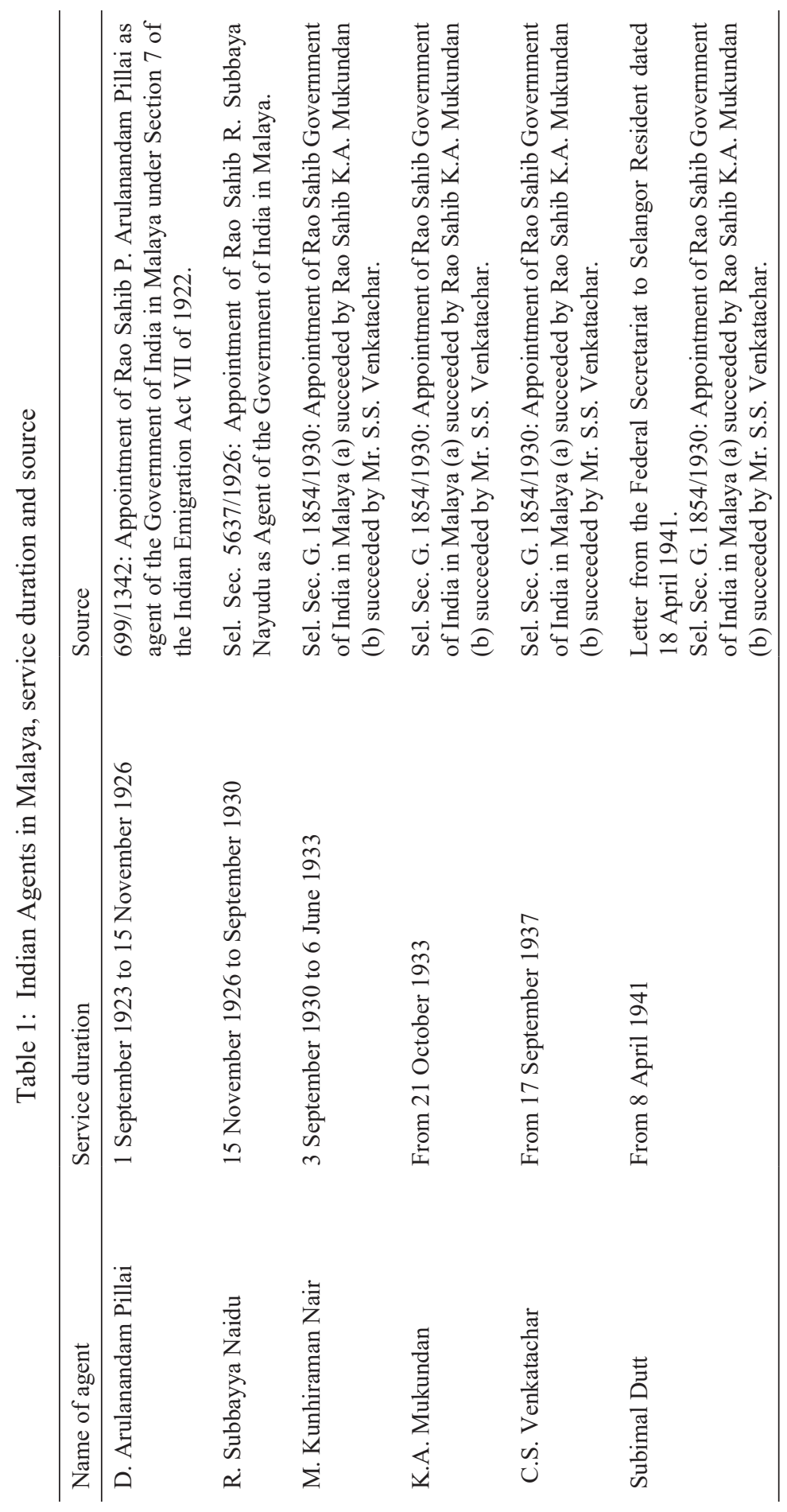


1919, which expanded the participation of local Indians to raise and discuss issues concerning the interests of fellow locals as well as those who emigrated and settled in other territories under British jurisdiction. This set the basis for nationalists and social critics to express concern about the deteriorating socioeconomic condition of south Indian labourers in British Malaya (Arasaratnam 1970; Ramasamy 2006). Commentators often raised the issue of their significant lag behind Chinese immigrants and disadvantaged status in the midst of rapid economic growth (Amrith 2015). As a result, members of the Congress Party of India called for the formal appointment of an Indian representative to oversee the welfare status of Indians living abroad, mostly the working class.

In the early 1920s, labour problems in Malaya were a major source of concern for the Indian government (Sundaram 1993). Increasing awareness of the various issues confronting domiciled Indian immigrants prompted the Indian government to criticise the Malayan government's lack of interest in addressing the socioeconomic disadvantages of south Indian labourers (Arasaratnam 1970). The Indian authorities then imposed stringent rules to protect them from exploitative recruiters. The Malayan government's numerous changes to the Labour Code were in fact in accordance with the Indian Emigration Act 1922, which allowed employers to provide their labourers with welfare facilities, primarily education and the abolition of punishments meted out for offences (Stenson 1980). The Indian Agents were appointed and charged with investigating labour conditions in Malaya under the authority of the act. While all Indian Agents generally supported the growth of a sense of political consciousness among Malaya's Indian communities, they also frequently emphasised the problem of the labouring class's socioeconomic underdevelopment.

The permanent settlement of south Indian labourers in Malaya was one of the issues that did not receive adequate attention from the Federated Malay States (FMS) Government, especially during the Great Depression of the late 1920s. The main issue was that the 1928 amendment to the Labour Code requiring estate managers to take responsibility for providing land allotments to their workers for subsistence agriculture was never broadly implemented (Parmer 1960). There was also the issue of a well-established control structure within Malayan plantations that limited south Indians to labouring functions, effectively disadvantaging them and preventing social mobility in the community (Ramasamy 1992; 1994). While most estate allotments were established during the 1930s recession, only a few labour allotments were seen to have progressed socioeconomically. With the exception of large estates such as Permatang 
in Selangor and Rubana in Perak, most estates struggled with a lack of land to allocate among their labourers (Ranie 2019). In addition, the FMS labour department's 1931 report noted estate management's lack of genuine interest in providing allotments for the socioeconomic benefits of their labourers (FMS Labour Department 1932). The lack of serious action by the government and private employers was largely due to the long-held perception that south Indian workers were essentially "birds of passage", wishing to leave the country with sufficient savings rather than settling permanently (FMS Labour Department 1939).

However, in the context of the Great Depression, the argument that south Indian labourers were transitory in nature and a stumbling block to the establishment of permanent settlement was unfounded. Despite the fact that many of them were repatriated, many preferred to stay and grow subsistence crops on the outskirts of estates for their immediate consumption (Amrith 2015). Furthermore, the FMS administration did not develop a comprehensive strategy to permanently settle them in the country. The inherent flaws and practical difficulties in allocating suitable lands for estate labourers remained unaddressed. In fact, the Labour Code did not prescribe any form of action to be taken against employers who did not comply with the regulation to provide their labourers with a means of subsistence living. Despite the fact that the FMS Labour Department did raise the issue of a lack of successful labour allotments, the Labour Controller, Chairman of the Indian Immigration Committee (IIC) and the Federal Legislative Council did not take it seriously.

The government's attitude towards permanent settlement of south Indian labourers contrasted sharply with its extensive effort beginning in 1913 to reserve vast tracts of land for Malay peasants in order to protect their socioeconomic interests under the Malay Reserves Enactment Act 1913 (Kratoska 1983). By the 1930s, Malay reserves in the country had taken up one-fourth of total state land allocations. Simultaneously, state lands were extensively used for commercial agricultural production. The government also favoured Chinese squatter farmers over south Indian labourers because the former were thought to be more enterprising (Sandhu 1969).

The aforementioned factors, ranging from practical difficulties faced by estate employers in land allocation to the FMS government's negative preconceived notions, all hindered the development of permanent settlements for south Indian labourers. Thus, this article assesses the degree to which the Indian Agents were able to resolve these issues and provide solutions for the establishment of Indian labour settlement for permanently domiciled south Indian labourers. 


\section{THE ROLES OF INDIAN AGENTS OF THE GOVERNMENT OF INDIA IN MALAYA}

While in Malaya, the Indian Agents published detailed reports titled Annual Report of the Agent of the Government of India in British Malaya, which examined the socioeconomic conditions of the Indian community, especially the workingclass. Their reports were based on evidence gathered during visits to working sites, especially plantations, investigations and interviews with Indian community members. Upon closer examination of the reports, four key components tended to be their main emphasis, namely land settlement, wage, Tamil education and the health condition of the working-class community. Aside from the issue of land allotment for south Indian labourers, which is the focus of this article, the Indian Agents were also involved in addressing the largely impoverished condition of Tamil schools and the educational underdevelopment of estate children, as well as the implementation of standard wage payment and the problem of toddy (palm wine) addiction among the labourers.

One of the issues that the Indian Agents identified as crucial in determining the overall socioeconomic well-being of the south Indian labour force was labour wage. This was particularly the case during the Great Depression, when the rubber industry suffered greatly. As a result of the fall in rubber prices, planters were forced to cut labour wages to considerably lower levels. Since production was stopped, labourers who were forced to accept low-wage employment faced socioeconomic hardships (Raja and Raymond 2018). They lacked the financial means to afford even the most essential needs, such as foodstuffs, which they lacked the disposition to cultivate (Huff 2001). It was at this point that Indian Agents had to step in and define the required amount of wage payment for estate labourers. They also brought their recommendations for standard wage implementation to the attention of the FMS Labour Department and the Labour Protectorate, with the aim of initiating corrective measures.

Indian Agents were also expected to intervene in the issue of Tamil vernacular education and schooling of children in the labour force. In this regard, issues that they had to address from time to time included a shortage of qualified instructors, inadequate infrastructural and educational facilities, and insufficient financial resources, all of which were found to be impediments to the development of Tamil education. The Indian Agents often criticised the small amount of government grants usually provided to Tamil estate schools in their reports and recommended that the amount of financial assistance be increased. Another socioeconomic issue that emerged in the midst of the existing financial and 
social difficulties was the overconsumption of toddy among the labourers, to the point where some succumbed to it. To break this harmful addiction, the Indian Agents would visit estates to raise awareness of the risks of toddy addiction to the well-being of the community.

In a nutshell, it was an Indian Agent's official duty to investigate all of the above issues pertaining to estate labourers and their families and report his findings, along with solutions to their problems. The need for an officially appointed colonial servant was justified by the fact that the British government in Malaya was unable to investigate and resolve all shortcomings due to its own political and economic commitments. The lack of progress in the opening of land settlement among the domiciled south Indian labourers resulted in the most visible involvement of the Indian Agents, necessitating an inquiry in this article.

\section{ARULANANDAM PILLAI}

The first Indian Agent, Arulanandam Pillai, was 53 years old when he was appointed by the Indian government to serve in Malaya in 1923. Given that the Indian Immigration Act of 1922 prioritised labour protection in terms of wage payment and the need to increase the gender ratio in the Indian labouring community, Pillai saw no urgent need to examine issues concerning the permanent settlement of south Indian workers (Kaur and Hoerder 2013). In fact, in the early 1920 s, the permanent settlement of the working-class had not yet become a cause of concern. Such a provision was rendered irrelevant by the availability of adequate numbers of south Indian labourers.

Pillai evidently concluded that the labourers did not own land until 1926. In his report, he stated clearly that land ownership was basically "nil" in the community, suggesting, not incorrectly, that the Indian labour class belonged to the non-landowning caste (Indian Agent 1927). He would have possibly noticed that the south Indian workers were not actively participating in land settlement. Few, if any, of them aspired to own land in the country. However, their reluctance or inability to settle was not the root of this problem. The real issue was that no legal obligation existed to require planters to allocate suitable estate lands for their labourers. Using his report as an indicator of his degree of involvement in the matter, Pillai can be said to have overlooked the problem of a lack of legal provisions, as well as the fact that settlement opportunities could have provided the Indian labour force with a stake in the country (Indian Agent 1927). 


\section{R. SUBBAYYA NAIDU}

Subbayya Naidu, a former Assistant Commissioner in the Madras Presidency's Chingelput district, was appointed the second Indian Agent to Malaya in 1926. It was only during his tenure that the issue of permanent labour settlement came to the attention of the British government. The influx of south Indian labourers from south Indian districts affected by prolonged drought at the time raised the possibility that their long-term settlement would be desirable in order to serve the plantation industry, especially in the FMS (The Straits Times 1926). The estimated number of 75,000 Indian immigrant labourers expected to enter the country in 1926 had been met within the first six months of the year (The Straits Times 1926). As a result, Naidu began to consider how to initiate settlement schemes to accommodate as many of them as possible. Unlike the government and planters, who were only interested in the possibility of maintaining a labour force, his motivation was guided more by the possibility of a settlement leading to securing a definite stake for the south Indian labouring community.

That permanent settlement of Indian labourers was one of Naidu's key agendas is clearly reflected in his 1927 report, which included a section titled Settlement of Indians on Land (Indian Agent 1928). However, Naidu discovered that there was a practical difficulty in convincing south Indian labourers to take up land because of their aversion to non-waging economic enterprise. This, he saw, was an impediment to the establishment of settlements. The majority of single and ablebodied labourers preferred estate employment to colonising lands (Sandhu 1969). As a result, some estate managers would only provide allotments when there was a demand from labourers (Indian Agent 1928).

According to Naidu, the government and planters should provide inducements for south Indians to develop an interest in taking up and cultivating their allotments. In his 1927 study, he expressed his skepticism about the actual appeal of the small-sized allotments typically granted in plantations for labourers to cultivate. Allotment size, in his view, was directly proportional to the degree of motivation that labourers would develop to cultivate on allotments. Naidu's central argument was that the amount of land allotted for cultivation was insufficient to entice them to cultivate a long-term interest in the country, and that if the government and planters wanted a more permanent labour force, large allotments were a crucial requirement (Sastri 1937).

His investigation into the degree to which the issue was being tackled in the country led him to take note of attempts made by Indian associations and individuals to establish settlements for Indian labourers in Malaya (Indian 
Agent 1929). In the late 1920s, he noted in his report, the All-Malayan Indian Conference, an organisation of various Indian groups, was able to obtain FMS Government approval to assign a Special Colonisation Officer to investigate and help start the initiative. There was also the recommendation by S. Krishnan, member of the Negeri Sembilan State Council that lands should be allocated to Indian immigrants. Naidu even met with him to discuss how to create permanent settlements for Indian labourers in Negeri Sembilan. Unfortunately, his collaboration with Naidu came to an end when the Indian Agent's service in Malaya ended in 1929 (Tamil Nesan 1938). Naidu was also the first to suggest that the settlement of Indian labourers on land could only be done by the adoption of a "sympathetic guidance" approach (Indian Agent 1929). The government's eventual acknowledgement of the approach was a nod to the fact that the Indian working class was unable to pursue independent land settlement. Naidu understood that only by some kind of official intervention could the community be permanently settled.

Naidu was also involved in investigating the feasibility of the Labour Code reforms made in relation to the settlement of Indian labourers. Although the size of land allocation of 1/16th per acre, as specified by the code amendment, may not necessarily induce a large number of estate labourers to begin cultivation, the Indian Agent was optimistic that south Indians would seize the opportunity to take up allotments to meet their immediate socioeconomic needs. His viewpoint was primarily founded on the fact that the Labour Code's implementation did, to a certain extent, compel some plantations to allocate lands to their labourers.

However, Naidu did point out that the absence of tenancy rights could inevitably cause south Indian labourers to lose interest in their allotments (Indian Agent 1930). He proposed that labourers with potential be granted entitlement rights to their holdings, with the FMS Government taking responsibility. In his reports, while Naidu seemed to agree with the economic need for establishing permanent labour force through settlement, he also noted that this was conditional on the grant of land titles. Naidu's relentless efforts forced the labour controller to circulate circulars across plantations, implementing the allocation of the 1/16th provision for south Indian labourers on estates (FMS Labour Department 1932). Similar circulars were also issued in Tamil by the Department of Agriculture.

Naidu was evidently determined to persuade the FMS government of the longterm economic benefits of granting south Indian labourers land entitlement rather than pro tem occupancy on allotments. He was, however, aware that estate plantations could never introduce large-scale settlement schemes because the undertaking would be too expensive. Most planters were worried that labourers 
would abandon estate duties and, ultimately, the estate itself. In that case, the Indian Agent acknowledged in his report the financial losses that employers would face, especially during the recession.

\section{KUNHIRAMAN NAIR}

The Great Depression disrupted Malaya's primary economic industries, especially rubber, resulting in mass repatriation of south Indian labourers and widespread unemployment among those who remained. When industrial operations resumed during the period of economic recovery, the FMS government and rubber planters were concerned about a serious labour shortage (Kim 1977). As a result of this situation, the government was forced to compel rubber producers to enforce the 1/16th provision (Indian Agent 1933). The policy was meant to give unemployed labourers the opportunity to cultivate food in order to relieve their hardship and keep them on estates (Indian Agent 1932). Kunhiraman Nair, the third Indian Agent and a former assistant collector in Malabar, was assigned to Malaya at the beginning of the Great Depression in 1930. He acknowledged the significance of the measure in addressing the problem of labour shortage. Nonetheless, he was more interested in the role of allotments in alleviating the socioeconomic difficulties of south Indian labourers.

Nair, like his predecessor, supported permanent settlement schemes for south Indian labourers, seeing them as the most suitable Depression-era socioeconomic measure and more appealing than temporary occupation on allotments with no tenure security. While he noted that the government was seriously enforcing the 1/16th amendment, such as when the Department of Agriculture published and distributed leaflets in Tamil across plantations, Nair was not fully convinced that it had any real intention of protecting the welfare of the labourers. Clearly, the Agent emphasised in his report that the issue had been long overdue and that there had been no progress in Indian permanent settlement (Indian Agent 1933; The Singapore Free Press and Mercantile Advertiser 1933b, 3).

Since his appointment as Indian Agent coincided with the recession, Nair had to engage in matters relating to the permanent settlement of south Indian labourers more actively than previous agents. Indeed, in 1932, he was active in settling a group of pioneering south Indians on state agricultural lands in what became known as the Chuah Tamil Settlement at Port Dickson in Negeri Sembilan. Another instance of his direct involvement was when he closely investigated and supervised the development of labour allotments on the Sua Betong Estate in the same state. 
The Chuah Settlement was rightly recognised as the model of successful land colonisation (Ranie 2019). Nair demonstrated the usefulness of sympathetic guidance by successfully guiding the pioneer-settlers. He first came across them as a group of destitute labourers roaming around Chuah. Some worked on Malay settlements and reserves, while others worked part-time on nearby coconut and rubber plantations. They wished to establish a settlement for themselves but were unable to obtain permission from state authorities to do so (Indian Agent 1933). At this point, Nair offered his assistance by guiding them through all legal procedures that they were unfamiliar with. After considering their ability and desire to settle permanently, Nair advised them that they should first acquire the lands on a leasehold basis for $\$ 1$ per acre.

He then negotiated with Negeri Sembilan state colonial officials, including the district officer, but the turning point came only when he obtained the permission of the state's British Resident to set aside a total of 243 acres of land in a forest reserve for the labourers to open and settle. Following approval, the district officer allocated four acres of land to each of the 39 settlers with family dependents; singles received two acres of land, and in some cases three acres. The most important arrangement Nair made for the settlers, with the cooperation of L.D. Gammons, Assistant Director of Cooperatives, was to place their settlement under the management of the Negeri Sembilan General Purposes Cooperative Society (Indian Agent 1933). The settlers were all allowed to engage in the management of the settlement by being members of the cooperative and investing a certain amount of savings into it to finance its development.

Nair, on the other hand, was well aware that occupancy issue might cause a problem. He started another round of negotiations with the authorities as soon as he was persuaded that the lands assigned to the labourers had been properly cultivated and entitled for partial ownership. In September 1932, Nair was able to obtain a temporary occupation license for the Chuah settlers. He also requested that the government take a sympathetic approach in assisting with the development of roads, drainage and a school for the settlement's 60 children. Meanwhile, Nair observed the settlement's progress in terms of agricultural and social development and proposed that the settlers be granted ownership rights to their lands. The Indian Agent then recommended to the government that the survey fee and premia be reduced as an inducement for permanent occupation (Indian Agent 1932). He also suggested allocating more land for the construction of a temple and cemetery, which the Indian Agent hoped would foster strong ties between the settlers and the settlement. 
Overall, it is undeniable that Nair was instrumental in the establishment and advancement of the Chuah Settlement. His roles in the case were well-observed and appreciated by several local newspapers. For example, in the Sunday Tribune (9 July 1933), he stated clearly his intention to make the Chuah Settlement scheme a major success. It also revealed his efforts to gain the cooperation of FMS authorities and educated elites in the Indian community. Taking all into account, the Sunday Tribune (9 July 1933) published the following remark on Nair:

The Chuah Settlement will remain a standing monument of the Rao Sahib's work in Malaya. It required the quiet and practical driving force of a man like Rao Sahib Kunhiraman Nair to secure government interest as well as the cooperation and the assistance of the educated Indian community in Seremban to launch the first Indian land settlement in Malaya.

Another prominent periodical, the Singapore Free Press and Mercantile Advertiser (1933a), also reported his deep involvement in the establishment of the Chuah Settlement, emphasising his confidence in maximising the potential of the labourers. The Singapore Free Press and Mercantile Advertiser (1933a) correspondent concluded his interview column with Nair by honouring him in the following words:

I cannot conclude this article without paying a tribute to the Rao Sahib [Kunhiraman] - to the practical view he took of the whole question by drawing up a workable settlement scheme on an experimental basis, to his perseverance and native ability in getting round a company of Indian labourers to give the scheme an honest and conscientious trial, and to the care and all round tact with which he has thus far, in happy conjunction with officials of this country, fostered it. He will get his full meed of praise when scheme fully and completely fructifies.

Nair's observation of the development of labour allotments on the Sua Betong estate is also noteworthy. Henderson, the estate manager, was mentioned in Nair's 1932 report as having implemented a large-scale scheme of allocating estate lands to his Indian employees in order for them to create settlements. Similarly to how Nair convinced the Chuah settlers to take up land, Henderson did the same by leasing lands to each of his labourers for 30 years at a fee of $\$ 1.50$ per acre. The first batch of 33 families and two single labourers received two acres for rice cultivation (Indian Agent 1933). The Indian Agent was prompted by Henderson's effort to state that estate managers should provide agriculturally arable land for the purpose of establishing labour settlements. He saw that this would not only 
ensure the permanent settlement of labourers, but would also allow them to meet their subsistence needs by cultivating food.

\section{K.A. MUKUNDAN}

In 1933, K.A. Mukundan, previously the assistant collector of the Tanjavore district, was appointed as the fourth Indian Agent to Malaya. By the time he was appointed, Indian labour settlement had become a contentious issue that could disrupt Malay-Indian relations (Kim 2006). The large number of Indian and Chinese immigrants had caused great concern among Malay leaders and the Malay masses, who feared losing their political and economic rights (Nadaraja 2016). Malay rulers were also dissatisfied with how the Malay states were losing their Malay identity. Due to his, Mukundan had to assuage Indian labourers' concerns about their future, particularly since the British had long maintained a pro-Malay policy (The Straits Times 1933).

Mukundan's primary responsibility in the issue of Indian land settlement was to oversee the establishment of the Chuah Tamil Settlement (Netto 1961). Mukundan, like Nair, was impressed with the settlement's rapid growth and continued to offer whatever assistance he could. In 1933, for example, he assisted the settlers in establishing a Tamil school, which was called Mukundan Padhasalai in recognition of Mukundan's contribution to the settlemen's growth (Jain 1966). The Indian Agent was also in charge of the construction of 30 houses as well as the extension of drainage to the Sepang River to prevent flooding (Indian Agent 1933). Mukundan was convinced that it was time to issue permanent occupation licenses to the Chuah settlers after being satisfied with their rapid socioeconomic development.

Mukundan also reported that labourers at the Sungei Ujong estate in Negeri Sembilan had successfully cultivated approximately 200 acres of agricultural land as part of a settlement scheme (Indian Agent 1934). This prompted him to argue that, contrary to common perception, south Indian labourers were capable of performing marketable agriculture (Indian Agent 1935). However, Mukundan, like his predecessors, recognised that a lack of land ownership and tenure insecurity had consistently prevented them from continuing to cultivate. Mukundan indicated in his report that even the settlers on the Sungei Ujong allotments were concerned that without occupation rights, they could be evicted without notification (Indian Agent 1936; The Straits Times 1936, 18). 
Furthermore, he insisted that the authorities consider granting land endowment to groups of labourers who had a genuine intention to cultivate, as was clearly illustrated in the case of the Chuah Settlement and the Kampong Padre Tamil Village at Bagan Serai, where successful development was owed largely to the fact that the lands belonged to the settlers (Fee, Manikam and Jain 1963). In addition to ownership, Mukundan emphasised that the allocation of suitable lands was critical to the socioeconomic advancement of south Indian labourers. To facilitate the progress of any labour settlement scheme in Malaya, he proposed that labourers with sufficient capacity and ability be identified and given lands to settle on and cultivate. This, Mukundan argued, would pave the way for the formation of a permanent workforce in the country (Indian Agent 1936).

However, one issue that went against the Indian Agent's recommendation was that most of the labourers saw cultivation as a short-term socioeconomic measure and preferred wage work to alleviate their hardships. In light of this problem, Mukundan requested that the FMS administration seriously and thoroughly consider adopting the approach of sympathetic guidance if there was any hope of persuading the labourers to settle permanently. He suggested the government should appoint officers to look into the ways in which official guidance could be extended for the establishment of permanent settlements for Indian workers (Indian Agent 1937). He proposed that the government appoint officers to examine how official guidance could be extended for the establishment of permanent settlements for Indian labourers (Indian Agent 1937). In this regard, Mukundan advised the government that simply seeing them as wage labourers would not be enough to permanently settle them, and that sufficient inducements should be considered necessary.

\section{C.S. VENKATACHAR}

C.S. Venkatachar, the first ICS officer to serve as an Indian Agent in Malaya, was appointed as the fifth Indian Agent in 1937. He, like the other Indian Agents, contributed to the permanent settlement of south Indian labourers in the country. The Indian Agent saw clearly that the settlement of available labourers was necessary after the Indian government banned all assisted immigration of unskilled Indian labourers to Malaya in 1938, in response to the Malayan Government's failure to comply with necessary labour employment conditions. The ban had a significant impact on the stability of the local labour force, forcing planters to prevent the outflow of existing labourers (The Straits Times 1939). Venkatachar, like Nair and Mukundan, believed that the settlement of Indian labourers should take into account their socioeconomic problems. As a result, 
he criticised most estates and the FMS government for failing to take into account the socioeconomic stability of the labourers they wanted to preserve. Venkatachar also argued that, even as late as 1937, most estates showed little interest in educating their labourers on how to use allotments to generate additional income (Raja and Raymond 2018). As a result, he explained, labourers were less likely to improve their holdings.

Venkatachar traced the lack of comprehensive development in Indian allotments in general to a lack of commitment from plantations and the government to fully enforce the 1/16th provision. He also observed that there were still inadequate inducements provided for labourers. Venkatachar also found that the size of allotment defined for allocation under the 1928 Labour Code was inadequate to entice labourers to begin cultivating. He suggested that a rubber plantation allocate at least two acres of land to a family of estate labourers who had worked for 20 to 24 days (Indian Agent 1938). Venkatachar also argued that estate managers should provide large allotments for their labour force in order to alleviate the looming food crisis during the recession by enabling them to cultivate for their own consumption. Simultaneously, he criticised some estate managers for cutting wage rates in order to force labourers to do gardening. The Indian Agent also saw allotment settlement as a crucial step in preventing social issues that would eventually occur as a result of the increasing labour population. Overall, like the previous Indian Agents, Venkatachar saw extensive land allotment schemes as a way for them to settle more permanently.

The Indian government was prompted by Venkatachar's report to appoint V.S. Srinivasa Sastri, the former Indian Agent to the Union of South Africa, to further investigate the socioeconomic status of Indian migrants in Malaya, especially the working class, in 1937 (Sastri 1937). In several respects, Sastri's report was a reaffirmation of the previous Indian Agents' observations (Ghee 1977). Based on their findings, Sastri concluded that one of the reasons estate owners could not offer permanent settlement to Indian workers - even though they wanted a stable labour force - was that most feared their labourers would not be able to sustain themselves on allotments. They were also legally allowed to leave the estate at any time with notice. Besides, Sastri suggested that the British may have thought there was no need to expand settlements for Indian labourers since Chinese labourers were already doing so and some of their crops were already receiving favourable responses from local markets (Sastri 1937). The High Commissioner, George Maxwell, was one of those officials who believed that south Indians were not as interested in agricultural cultivation as their Chinese counterparts (The Straits Times 1935). It should be noted that the primary difference between Sastri and the Indian Agents, especially 
Nair and Mukundan, is that the former largely avoided providing an accurate representation of the social conditions of Indian labourers in Malaya, while the latter were more forthright in their observations.

\section{SUBIMAL DUTT}

In comparison to previous Indian Agents, Subimal Dutt, the sixth Indian Agent appointed in 1941 and a former ICS officer, was unable to address the issue of permanent settlement of Indian workers in his 1940 report (Indian Agent 1941). One of the reasons was that his arrival in the country coincided with a time of gradual economic growth, which resulted in the resumption of rubber production and, as a result, labour wage stabilisation (Indian Agent 1941). Therefore, the majority of labourers returned to rubber-tapping, while others took parttime work on plantations. Many who had received allotments at the height of the recession started to leave their holdings. Furthermore, the labourers only saw wage labour as a way of securing a consistent source of income. Since some were forced to work long hours on estate to raise extra money, they were unable to garden on allotments. Dutt, on the other hand, was worried about the well-being of the community. In one case, the Indian Agent urged Indian organisations to take greater responsibility and interest in resolving the welfare issues of Indian labourers (The Straits Times 1941a).

Unlike the previous Indian Agents, he did not see that introducing permanent settlement schemes for south Indian labourers would solve the problem of labour shortage. Furthermore, the Indian government did not specifically request that Dutt report on this issue. Nonetheless, the Indian Agent expressed a desire to investigate various estates and other places where Indian labourers were working (Morning Tribune 1941). Since his time in Malaya coincided with the impending outbreak of World War II, his primary concern was war efforts, specifically the degree to which Indians in Malaya could contribute to the cause of the Allies (The Straits Times 1941b). It was also not long before the Japanese occupied the region, dramatically altering the socioeconomic status of south Indian labourers when the majority were forcefully conscripted to work on the Siam-Burma or Death Railway. After the war, during the intervening period of the British Military Administration, the issue of Indian land settlement was largely ignored. 


\section{CONCLUSION}

Despite the obvious master-servant relationship between the Indian Agents and the British colonial government, some of the Indian Agents who served in Malaya had considerable autonomy in matters relating to Indian land settlement. They had some leeway in conducting their investigation of Indian labour issues, including the community's lack of progress in land colonisation. Furthermore, the Indian Agents were not subordinated to Malayan authorities, but rather to the Indian government, for whom they actually performed their duties. The amount of liberty they were thus able to exercise in Malaya can be vouched for by the fact that the Indian Agents used their influence to press the Malayan government into taking a more helpful approach for Indian labourers to settle permanently on lands and, on occasion, to criticise them for failing to do so.

With the exception of Pillai and Dutt, all Indian Agents who served in Malaya were conscious that the establishment of permanent settlements for Indian labourers was vital to alleviating their socioeconomic hardships. It was through their research and observations that Malayan officials were made aware of the problem of such settlements not developing to a significant extent in the FMS. Various inherent problems impeding the establishment of permanent settlement for south Indian labourers were effectively communicated to the government. The annual Indian Agent report was the primary means of reporting and documenting the community's lack of progress in settlement development. It was also used to express to the Indian and FMS governments the importance of providing sympathetic guidance to help them settle more permanently. However, Indian Agents did not seem to be able to take effective action or exercise significant influence in matters pertaining to estate allotments. Since estates were essentially private establishments, they could only provide suggestions and overviews of the issues concerning allotment development.

Nonetheless, there is no denying that the majority of Indian Agents were instrumental in stressing to Malayan officials the socioeconomic importance of permanent labour settlements. Although the first Indian Agent, Pillai, was not especially helpful in this regard, his successors were. For example, Naidu, the second Indian Agent, suggested that the government grant land ownership rights to potential labourers and criticised the impracticability of existing provisions. Naidu also reminded the government on a regular basis that if it wanted to ensure their permanent settlement in the country, it needed to first address land ownership and allotment size. Later, Nair and Mukundan found that a lack of initiative among the workers to cultivate was a major stumbling block. It was later found that most labourers actually lacked the ability to engage in long-term 
cultivation. The latter two Indian Agents' most important finding was that most private employers were indifferent to the underdevelopment of labour holdings. During the 1930s Great Depression, Venkatachar, the fifth Indian Agent, was more open in voicing his opinion that estate managements and south Indian labourers failed to fully grasp the value of labour allotments in fulfilling mutual economic interests.

It is worth noting that the degree of independence that the British-appointed Indian Agents possessed and used for the benefit of the Indian labour community during their stints in Malaya may indicate that, contrary to common belief, colonialism was not entirely destructive. It was, at least in some cases, such as migrant land settlement in Malaya, constructive. The Indian government sent Indian Agents to Malaya to investigate problems affecting Indians, many of which were correctly identified, and others, such as land settlement, were resolved. Future research, however, will be needed to determine whether colonialism was indeed constructive in a broader context.

Nonetheless, in the case of Indian Agents' involvement in matters relating to Indian labour settlements, colonial politics did not prevent them from reporting on the actual state of affairs. They also did not exhibit a submissive attitude. The Indian Agents took a strong stance in reporting British reluctance to establish permanent settlements for south Indians in Malaya. They were also forthright in stating that an unofficial preference was shown for the land settlement of Chinese labourers. The roles of Naidu, Nair, Mukundan, Venkatchar and Dutt in highlighting the socioeconomic difficulties of Indian labourers prompted local leaders to start advocating for the community's welfare. While some Indian Agents were clearly more committed than others, their presence provided some sort of representation for the community, especially for working class Indians. Overall, the Indian Agents did everything in their capacity to convince colonial authorities and private employers of the value of permanent Indian settlement.

\section{REFERENCES}

\section{Primary Source}

699/1342: Appointment of Rao Sahib P. Arulanandam Pillai as agent of the Government of India in Tanah Melayu under Section 7 of the Indian Emigration Act VII of 1922.

FMS Labour Department. 1932. Annual report 1931. Kuala Lumpur: Government Press. 1939. Annual report 1938. Kuala Lumpur: Government Press. 
Indian Agent. 1927. Annual report of Agent of the Government of India in British Malaya for the year 1926. Calcutta: Government of India, Central Publication Branch. . 1928. Annual report of Agent of the Government of India in British Malaya for the year 1927. Calcutta: Government of India, Central Publication Branch. 1929. Annual report of Agent of the Government of India in British Malaya for the year 1928. Calcutta: Government of India.

1930. Annual report of Agent of the Government of India in British Malaya for the year 1929. Calcutta: Government of India.

. 1932. Annual report of Agent of the Government of India in British Malaya for the year 1931. Delhi: Manager of Publication.

. 1933. Annual report of Agent of the Government of India in British Malaya for the year 1932. Delhi: Manager of Publication.

. 1934. Annual report of Agent of the Government of India in British Malaya for the year 1933. Delhi: Manager of Publication.

. 1935. Annual report of Agent of the Government of India in British Malaya for the year 1934. Delhi: Manager of Publication.

. 1936. Annual report of Agent of the Government of India in British Malaya for the year 1935. Delhi: Manager of Publication.

. 1937. Annual report of Agent of the Government of India in British Malaya for the year 1936. Delhi: Manager of Publication.

1938. Annual report of Agent of the Government of India in British Malaya for the year 1937. Delhi: Manager of Publication.

1941. Annual report of Agent of the Government of India in British Malaya for the year 1940. Delhi: Manager of Publication.

Letter from the Federal Secretariat to Selangor Resident dated 18 April 1941.

Sel. Sec. G. 1854/1930: Appointment of Rao Sahib Government of India in Tanah Melayu (a) succeeded by Rao Sahib K.A. Mukundan (b) succeeded by Mr. S.S. Venkatachar (a).

Sel. Sec. 5637/1926: Appointment of Rao Sahib R. Subbaya Nayudu as Agent of the Government of India in Tanah Melayu.

\section{Secondary Source}

Amrith, S.S. 2015. Connecting diaspora histories: Indians and Chinese in colonial Malaya. In Indian and Chinese immigrant communities: Comparative perspectives, 13-24. Singapore: Institute of Southeast Asian Studies.

Arasaratnam, S. 1970. Indians in Malaysia and Singapore. Kuala Lumpur: Oxford University Press.

Belle, C.V. 2015. Tragic orphans: Indians in Malaysia. Singapore: Institute of Southeast Asian Studies.

Fee, F., F. Manikam and R.K. Jain. 1963. Kampong Padre: A Tamil settlement near Bagan Serai, Perak. Journal of the Malayan Branch of the Royal Asiatic Society 36(1): 153-181.

Ghee, L.T. 1977. Peasants and their agricultural economy in colonial Malaya, 18741941. Kuala Lumpur: Oxford University Press. 
Huff, W.G. 2001. Entitlements, destitution, and emigration in the 1930s Singapore Great Depression. The Economic History Review 54(2): 290-323.

Jain, R.K. 1966. Ramanathpuram experiment: Paradigm of an estate-farm-factory community in Malaya. Proceedings of the First International Conference Seminar of Tamil Studies. Kuala Lumpur: International Association of Tamil Research.

Kaur, A. and D. Hoerder, eds. 2013. Understanding international migration: Comparative and transcultural perspectives. In Proletarian and gendered mass migrations: A global perspective on continuities from the 19th to the 21st centuries, 1-18. Leiden: Brill.

Kim, K.K. 1977. The Great Depression: The Malaysian context. In The history of SouthEast, South and East Asia: Essays and documents, 78-94. Kuala Lumpur: Oxford University Press.

2006. Malay attitude towards Indians. In Indian communities in Southeast Asia, 266-287. Singapore: Institute of Southeast Asian Studies.

Kratoska, P. 1983. Ends that we cannot foresee. Journal of Southeast Asian Studies 14(1): 149-168.

Morning Tribune. 1941. 9 April.

Nadaraja, K. 2016. Malay reaction to the 1930s economic depression in Malaya. Jebat: Malaysian Journal of History, Politics \& Strategic Studies 43(1): 46-64.

Nair, M.N. 1937. Indians in Malaya. Koduvayar: Koduvayar Press.

Netto, G. 1961. Indians in Malaya: Historical facts and figures. Singapore: George Netto.

Parmer, J.N. 1960. Colonial labor policy and administration: A history of labor in the rubber plantation industry: Malaya, c. 1910-1941. New York: J.J. Augustin for the Association for Asian Studies.

Raghavan, N. 1954. India and Malaya: A study. Bombay: Indian Council of WorldAffairs/ Orient Longman.

Raja, S.S. and S. Raymond. 2018. The lost race in British Malaya: Revisiting the problems of South Indian labourers. Diaspora Studies 11(2): 115-134.

Ramasamy, P. 1992. Labour control and labour resistance in the plantations of colonial Malaya. The Journal of Peasant Studies 19(3-4): 87-105. 1994. Plantation labour, unions, capital, and the state in peninsular Malaysia. New York: Oxford University Press.

2006. Socio-economic transformation of Malaysian Indian plantation workers. In Indian communities in Southeast Asia, 314-333. Singapore: Institute of Southeast Asian Studies.

Ranie, T. 2019. The role of agricultural settlements in alleviating the socioeconomic deprivation among south Indian labourers in the Federated Malay States, 18961941. Masters diss., University of Malaya.

Sandhu, K.S. 1969. Indians in Malaya: Some aspects of their immigration and settlement (1786-1957). Cambridge: Cambridge University Press.

Sastri, V.S.S. 1937. Reprint of report on the conditions of Indian labour in Malaya. Kuala Lumpur: Federated Malay States Press.

Stenson, M. 1980. Class, race and colonialism in West Malaysia. St. Lucia: University of Queensland Press. 
Sundaram, J.K. 1993. Plantation capital and Indian labour in colonial Malaya. In Indian communities in Southeast Asia, 288-314. Singapore: Times Academic Press.

Sunday Tribune. 1933. 9 July.

Tamil Nesan. 1938. 15 September.

The Singapore Free Press and Mercantile Advertiser. 1933a. 1 February. 1933b. 23 June.

The Straits Times. 1926. 14 December. 1933. 9 November. 1935. 15 December. 1936. 20 November. 1939. 25 November. 1941a. 26 May. 1941b. 16 June.

Witherington, C.A. 1937. The new constitution of India: A brief survey. The Australian Quarterly 9 (1): 32-45. 